\title{
The effect of flucytosine on the germination of Candida albicans
}

\author{
William H. WaIN \\ Ph.D.
}

\author{
AnNemarie PolaK* \\ Dr sc. nat.
}

\author{
National Heart Hospital, Westmoreland Street, London, and Cardiothoracic Institute, \\ Beaumont Street, London, and *Pharmaceutical Research Division, Hoffmann-La Roche Ltd, Basle
}

\section{Summary}

The effect of flucytosine on the germination of 3 strains of Candida albicans in serum was tested. No inhibition of germination was observed and it was concluded that germination did not require the synthesis of DNA.

\section{Introduction}

Recent studies with Candida albicans have revealed that there are at least 2 fundamentally different modes of action for flucytosine (Arai et al., 1977; Polak and Wain, 1977, 1978; Diasio, Myers and Bennett, 1978). The incorporation of the deaminated metabolite 5-fluorouracil (5-FU) into RNA was investigated by Giege and Weil (1970), and the implications of different malfunctionings in the pathways of uptake and incorporation have been described by Polak and Scholer (1975). Another metabolite of flucytosine, 5-fluorodeoxyuridine monophosphate has been detected by Diasio, Bennett and Myers (1978) and they also demonstrated an inhibition of thymidylate kinase. Arai et al. (1977) ascribed the morphological changes induced by flucytosine to an inhibitor of DNA synthesis and Polak and Wain $(1977,1978,1979)$ have shown that total DNA increase, hyphal nuclear division and thymidine incorporation into DNA are all inhibited by flucytosine. Polak and Wain (1978, 1979) also showed that abnormal yeast cell shapes (Arai et al., 1977; Polak and Wain, 1978) were due to abnormal, accelerated carbohydrate synthesis. These 2 modes of action have been shown to apply to both yeast and hyphal phases of $C$. albicans (Polak and Wain, 1979) and to affect budding in the yeast phase (Arai et al., 1977; Polak and Wain, 1977, 1978). Polak and Wain (1977, 1978, 1979) demonstrated a clear inhibition of hyphal elongation by flucytosine and this inhibition was seen in cultures which had germinated to at least $90 \%$ before the addition of the drug. Arai et al. (1977) said that the even in the presence of flucytosine. The control of germination by $C$. albicans on inoculation into serum or other biological fluids is still not clear and the action of flucytosine on both macromolecular germ-tube formation did not seem to be affected synthesis and germination during the first few hours after inoculation into serum have therefore been investigated.

\section{Materials and methods}

Three strains of $C$. albicans sensitive to flucytosine (MIC $0.5 \mathrm{mg} / \mathrm{l}$ ) and selected for their consistent ability to form hyphae in serum were maintained on Sabouraud's malt agar. Overnight cultures, termed early stationary phase cultures, were inoculated into pooled human serum at $37^{\circ} \mathrm{C}$. The serum had been filtered through $0.45 \mu \mathrm{m}$ pore size membrane filter (Millipore) and contained either flucytosine or cytosine to a concentration of $100 \mu \mathrm{g} / \mathrm{ml}$. The non-budding cells were inoculated to a concentration of $1.5 \times 10^{6} / \mathrm{ml}$ and cultured at $37^{\circ} \mathrm{C}$ with shaking. Samples were taken at intervals to measure germination, hyphal elongation rates and DNA, RNA, protein and carbohydrate amounts (Polak and Wain, 1977, 1979). All experiments were repeated at least twice with all 3 strains.

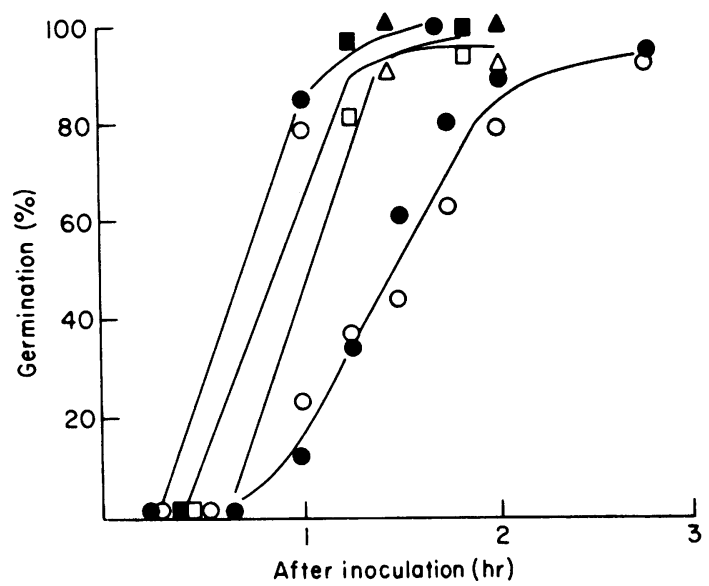

Fig. 1. The germination of Candida albicans in serum in the presence of flucytosine.

$$
\begin{array}{llll}
4 & 5 & 10 & \\
\bigcirc & \square & \triangle & \text { cytosine } \\
& \square & \triangle & \text { flucytosine }
\end{array}
$$




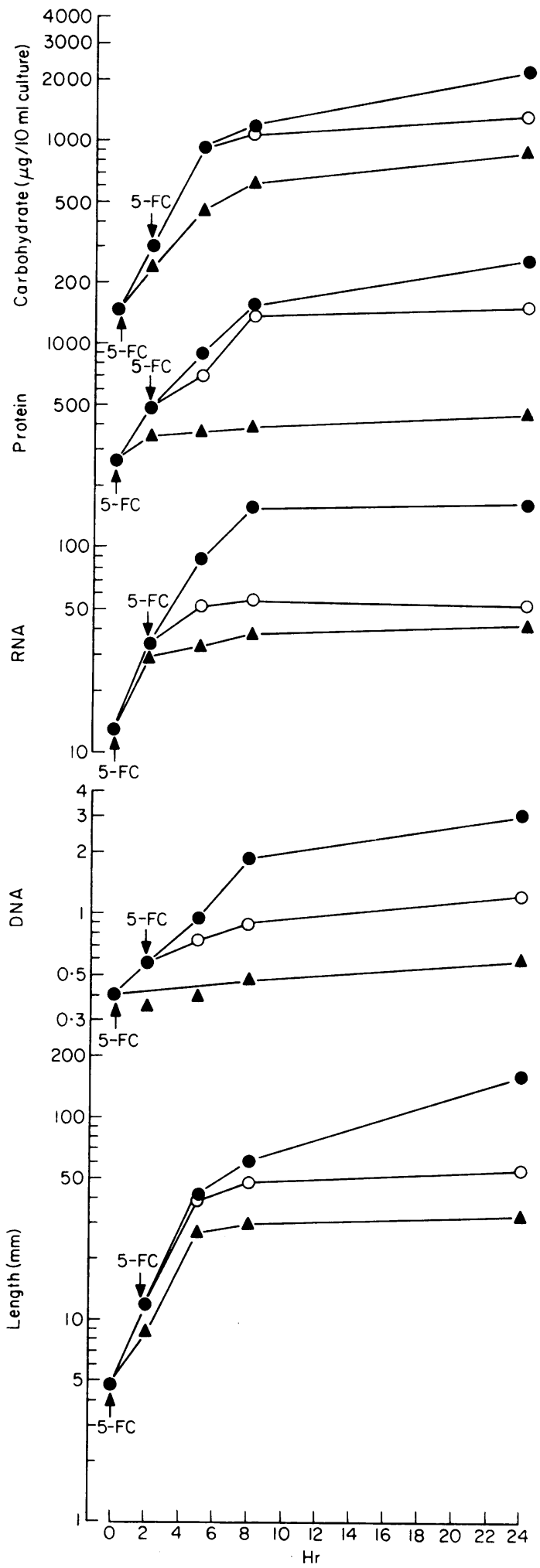

\section{Results}

It was very clear from Fig. 1 that flucytosine did $>$ not affect the germination of $C$. albicans in serum. Moreover, the only immediate effect of flucytosine $C$ was on the increase in DNA (Fig. 2). Unlike the exponentially growing hyphae used by Polak and Wain $(1977,1978,1979)$ there was not a parallel inhibition of RNA increase in the germinating cells. The effect on the RNA was seen several hours later in the growing, germinated hyphae.

\section{Discussion}

Although flucytosine is an inhibitor of both RNA and DNA synthesis in exponentially growing cells, it does not influence the germination in serum.

Investigations with synchronous cultures of both yeast and hyphal phases of $C$. albicans have shown that yeast budding follows the first period of DNA of synthesis whereas hyphal germination precedes it 8 (Wain et al., 1976). The slower manifestation of $v$ abnormal carbohydrate synthesis produced by flucytosine is unlikely to affect germination, which occurs within the first $2 \mathrm{hr}$ of inoculation into serump Similarly, although DNA synthesis is more rapidlo affected than carbohydrate synthesis, since gers $\mathbb{D}$ mination precedes DNA synthesis, any inhibition of DNA synthesis, however rapid, should not affect germination.

Germination is thus seen to be an event which doe? not require the synthesis of DNA and which cait proceed in the presence of an RNA inhibitor. The lack of similarity between RNA and DNA in response to flucytosine during germination lends further support to the idea that the influence of flucytosine on RNA synthesis is also mediated by the action on DNA. The information for germination is immediately available from the existing DNA in response to some factor or factors which induce germination.

FIG. 2. Rate of hyphal elongation and increase in DNA, RNA, protein and carbohydrate content of Candida albicans in the presence of flucytosine (5-FC).

Control; $\mathrm{O} \longrightarrow$ 5-FC added at $2 \mathrm{hr} ; \Delta-\Delta$ 5-FC added at $0 \mathrm{hr}$.

\section{References}

Arai, T., Mikami, T., Yokoyama, K., Kawata, T. \& MAsudA, K. (1977) Morphological changes in yeasts as a $\mathrm{N}$ result of the action of 5-fluorocytosine. Antimicrobial Agents and Chemotherapy, 12, 255.

Diasio, R.B., BenNetT, J.E. \& MYeRs, C.E. (1978) The mode of action of 5-fluorocytosine. Biochemical Pharmacology, 27, 703

GIEGE, R. \& WeIL, J.H. (1970) Etudes des t-RNA de levure ayant incorporé du 5-fluorouracil provenant de la déamination in vivo de la 5-fluorocytosine. Bulletin de la Société de chimie biologique, 52, 135. 
Polak, A. \& Scholer, H.J. (1975) Mode of action of 5fluorocytosine and mechanisms of resistance. Chemotherapy, 21, 113.

Polak, A. \& WaIN, W.H. (1977) The influence of 5-fluorocytosine on nucleic acid synthesis in $C$. albicans, $\mathrm{Cr}$. neoformans and $A$. fumigatus. Chemotherapy, 23, 243.

Polak, A. \& WaIN, W.H. (1978) New aspects of the mode of action of 5FC. In: Chemotherapy of Fungal Diseases Proceedings of the 10th International Congress of Chemo- therapy (1977). (Ed. by Siegenthaler, W. \& Lüthy R.). Current Chemotherapy, 1, 213.

Polak, A. \& WaIN, W.H. (1979) The effect of 5-fluorocytosine on the blastospores and hyphae of Candida albicans. Journal of Medical Microbiology, 12, 83.

Wain, W.H., Price, M.F., Brayton, A.R. \& Cawson, R.A. (1976) Macromolecular synthesis during cell cycles of yeast and hyphal phases of Candida albicans. Journal of General Microbiology, 97, 211. 